\title{
Evidence that Cell Surface Heparan Sulfate Is Involved in the High affinity Thrombin Binding to Cultured Porcine Aortic Endothelial Cells
}

\author{
Kazuyuki Shimada and Toshio Ozawa \\ Division of Cardiovascular Disease, Department of Medicine and Geriatrics, Kochi Medical School, Nankoku-shi, Kochi 781-51, Japan
}

\begin{abstract}
It has been postulated that thrombin binds to endothelial cells through, at least in part, cell surface glycosaminoglycans such as heparan sulfate, which could serve as antithrombin cofactor on the endothelium. In the present study, we have directly evaluated the binding of ${ }^{125}$ I-labeled bovine thrombin to cultured porcine aortic endothelial cells. The thrombin binding to the cell surface was rapid, reversible, and displaced by enzymatically inactive diisopropylphosphoryl-thrombin. The concentration of thrombin at half-maximal binding was $\sim 20 \mathrm{nM}$. Both specific and nonspecific binding of ${ }^{125} \mathrm{I}$-thrombin to the endothelial cell surface was partially inhibited in the presence of protamine sulfate, after the removal of cell surface heparan sulfate by the treatment of cells with crude Flavobacterium heparinum enzyme or purified heparitinase. The binding as a function of the concentration of thrombin revealed that the maximal amount of specific binding was reduced by $\sim 50 \%$ with little alteration in binding affinity by these enzymatic treatments. The reversibility and active-site independence as well as the rate of the binding did not change after heparitinase treatment. Whereas removal of chondroitin sulfates by chondroitin ABC lyase treatment of cells did not affect the binding, identical enzymatic treatments of ${ }^{35}$ S $]$ sulfate-labeled cells showed that either heparan sulfate or chondroitin sulfate was selectively and completely removed from the cell surface by heparitinase or chondroitin ABC lyase treatment, respectively. Furthermore, proteolysis of cell surface proteins by the purified glycosaminoglycan lyases was excluded by the identical enzymatic treatments of $\left[{ }^{3} \mathbf{H}\right]$ leucine-labeled or cell surface radioiodinated cells. Our results provide the first direct evidence that heparan sulfate on the cell surface is involved in the high-affinity, active site-independent thrombin binding by endothelial cells, and also suggest the presence of thrombin-binding sites that are not directly related to heparan sulfate.
\end{abstract}

\section{Introduction}

It is widely accepted that an intact healthy vascular endothelium plays a significant role in maintaining normal blood fluidity by presenting a noncoagulant-nonthrombogenic surface to circulating blood constituents $(1,2)$. In the course of studies on fundamental mechanisms of this important cellular function, the endothelial cell surface has recently been shown to remove thrombin, the most important activated coagulation factor,

Address correspondence to Dr. Shimada.

Received for publication 18 April 1984 and in revised form 5 November 1984.

J. Clin. Invest.

(C) The American Society for Clinical Investigation, Inc.

0021-9738/85/04/1308/09\$1.00

Volume 75, April 1985, 1308-1316 from the circulation and to accelerate the thrombin-antithrombin III reaction (3-7). Data obtained in vivo and in vitro have indicated that the rapid inhibition of thrombin requires binding of thrombin to the high-affinity binding sites on the endothelium (3-5), and that the endothelial antithrombin III cofactor has functional properties in common with the anticoagulant glycosaminoglycans, heparin, and heparan sulfate (7-9). Glycosaminoglycans such as heparan sulfate have been reported to be surface components of endothelial cells in vitro (10) and in vivo (11). Thus, it has been postulated that a heparinlike substance present on the endothelial cell surface is responsible for the high-affinity binding of thrombin and catalysis of the thrombin-antithrombin III reaction $(2,12)$.

Radiolabeled or unlabeled thrombin has been shown to bind to cultured endothelial cells or intact endothelium (1318). Few studies so far have investigated the role of glycosaminoglycans in these bindings, and those that did employed only indirect methods. These studies have included testing the effects of chemical modifications to the heparin-binding site of thrombin on the binding of thrombin to endothelial cells (18) and the comparison of thrombin binding to vascular endothelium with that of thrombin to artificial surfaces containing glycosaminoglycans such as heparin and heparan sulfate (9). The data obtained by these techniques, on the one hand, have been consistent with the proposed hypothesis of the binding of thrombin to glycosaminoglycans. On the other hand, interactions of thrombin with endothelium have been demonstrated to result in several other biological effects on these cells (19), including protein $\mathrm{C}$ activation by a complex between thrombin and thrombomodulin, an endothelial cell surface cofactor (20). A number of the effects of thrombin on endothelial cells are not apparently related to glycosaminoglycans on the cells. Thus, important questions exist regarding the binding of thrombin by the endothelial cell. Are glycosaminoglycans such as heparan sulfate on the endothelial cell surface involved in the high-affinity binding sites for thrombin? If so, to what extent?

In a previous report, we presented data describing the interaction between lipoprotein lipase and endothelial cells, in which the presence of cell surface glycosaminoglycans was related to the binding of lipoprotein lipase (21). In the present study, we provide the first direct evidence that cell surface heparan sulfate is, at least in part, also involved in the highaffinity binding of thrombin to endothelial cells.

\section{Methods}

Materials. Bovine serum albumin (essentially fatty acid-free), protamine sulfate, chondroitin sulfate (mixed isomers), trypsin, and glucose oxidase were obtained from Sigma Chemical Co., St. Louis, MO. Lactoperoxidase was obtained from Miles Laboratories, Goodwood, South Africa. Lactoperoxidase glucose oxidase reagent (Enzymobead) and Bio-Gel P-6DG were purchased from Bio-Rad Laboratories, Richmond, CA. RPMI-1640 medium, Hanks' balanced salt solution 
without phenol red, Dulbecco's phosphate-buffered saline, and fetal calf serum were obtained from Grand Island Biological Co., Grand Island, NY. Petri dishes $(35 \times 10 \mathrm{~mm})$ were products of Falcon Labware, Cockeysville, MD. Diisopropylfluorophosphate (DFP) ${ }^{1}$ was obtained from Fluka AG, Buchs, Switzerland. Tosyl-glycine-prolinearginine-p-nitroanilide was obtained from Pentapharm Ltd., Basel, Switzerland. $\mathrm{Na}^{125} \mathrm{I}(17 \mathrm{Ci} / \mathrm{mg})$ was obtained from New England Nuclear, Boston, MA. $\left[{ }^{3} \mathrm{H}\right]$ leucine $(131 \mathrm{Ci} / \mathrm{mmol})$ was obtained from Amersham Corp., Arlington Heights, Ill. $\left[{ }^{35}\right.$ S $]$ sulfate (carrier-free, 22 $\mathrm{mCi} / \mathrm{ml}$ ) was obtained from the Japanese Atomic Energy Research Institute, Ibaragi, Japan. Bovine fibrinogen with a coagulability of $98 \%$ was purchased from Daiichi Kagaku, Tokyo. Pronase was obtained from Kaken Chemicals Co., Tokyo. Dispase was a product of Godo Shusei Co., Tokyo. Heparitinase and chondroitin $\mathrm{ABC}$ lyase was obtained from Seikagaku Kogyo, Tokyo. Crude Flavobacterium heparinum enzyme prepared from $F$. heparinum (22) was provided by Dr. T. Okuyama, Tokyo. Captopril was a generous gift from Sankyo Co., Tokyo. All other materials were reagent grade.

Endothelial cell cultures. Aortic endothelial cells were isolated from the descending thoracic aorta from pigs immediately after death, and were cultured as previously described (21), with minor modifications. Aorta segments $10 \mathrm{~cm}$ in length were drained of excess Dulbecco's phosphate-buffered saline containing antibiotics $(100 \mathrm{U} / \mathrm{ml}$ penicillin, $100 \mu \mathrm{g} / \mathrm{ml}$ streptomycin, and $1.25 \mu \mathrm{g} / \mathrm{ml}$ amphotericin B). The intercostal arteries were closed with clamps, and one end was closed with a hemostat. The aorta was then filled with 5-10 ml of Dispase $(1,000$ $2,000 \mathrm{U} / \mathrm{ml}$ ) in RPMI- 1640 medium containing $5 \%$ calf serum, and incubated for $15-20 \mathrm{~min}$ at $37^{\circ} \mathrm{C}$. The Dispase solution was collected and the lumen of the vessels was rinsed once with cold phosphatebuffered saline. These fractions were pooled, and further phosphatebuffered saline was added so that the concentration of Dispase was finally diluted fivefold. The cells were sedimented at $160 \mathrm{~g}$ for $6 \mathrm{~min}$ at $4^{\circ} \mathrm{C}$, and placed into $35-\mathrm{mm}$ petri dishes containing RPMI- 1640 medium supplemented with $10 \%$ fetal calf serum and antibiotics as above. These cultures were incubated at $37^{\circ} \mathrm{C}$ in a humidified atmosphere of $5 \% \mathrm{CO}_{2}$ in air for $\sim 7 \mathrm{~d}$ before use at subconfluence. Only primary cultures of endothelial cells were used.

Characterization of the primary cultures showed the typical microscopic cobblestone appearance of endothelial cells and contact inhibition in monolayer culture. To confirm the identity of cultured endothelial cells, angiotensin-converting enzyme activity was measured in the cell homogenates according to the colorimetric method described by Kasahara and Ashihara (23). The enzymatic activity that could be inhibited by $2 \mu \mathrm{M}$ of captopril was $182 \pm 59 \mathrm{nmol}$ histidyl-leucine per $\mathrm{mg}$ of cell protein per $\mathrm{h}$ (mean $\pm \mathrm{SE}$ of 15 determinations), whereas essentially no activity was found in cultured subendothelial cells of several passages.

Thrombin preparations. Bovine $\alpha$-thrombin was a generous gift from Dr. T. Morita, Department of Biology, Kyushu University, Fukuoka, Japan and was prepared as previously described (24). It was essentially homogenous as judged by sodium dodecyl sulfate-polyacrylamide gel electrophoresis (25). The specific activity was approximately $3,900 \mathrm{NIH} \mathrm{U} / \mathrm{mg}$ of protein based on an extinction coefficient $\left(E_{280}^{1 \%}\right)$ of 21.4 .

For some experiments, thrombin was inactivated by incubation with $0.01 \mathrm{M}$ DFP in $0.05 \mathrm{M}$ Tris- $\mathrm{HCl}(\mathrm{pH} 8.0)$ containing $0.2 \mathrm{M} \mathrm{NaCl}$ for $10 \mathrm{~min}$ at room temperature $\left(\sim 22^{\circ} \mathrm{C}\right)$. The DFP-inhibited thrombin (diisopropylphosphoryl [DIP]-thrombin) was then dialized against 0.05 $M$ sodium phosphate (pH 6.0) containing $0.25 \mathrm{M} \mathrm{NaCl}$ at $4^{\circ} \mathrm{C}$ for $16 \mathrm{~h}$.

Radioiodination of thrombin. Purified bovine thrombin was labeled with ${ }^{125} \mathrm{I}$ by the lactoperoxidase method, using solid-phase radioiodination reagent (Enzymobead). The reaction mixtures consisted of $50 \mu \mathrm{l}$ of Enzymobead rehydrated according to the manufacturer's instructions, $25 \mu \mathrm{l}$ of $0.07 \mathrm{M}$ sodium phosphate buffer (pH 6.8) containing $0.2 \mathrm{M}$

1. Abbreviations used in this paper: DFP, diisopropylfluorophosphate; DIP, diisopropylphosphoryl.
$\mathrm{NaCl}, 50 \mu \mathrm{l}$ of purified thrombin $(40 \mu \mathrm{g}), 10 \mu \mathrm{l}$ of $0.5-1 \mathrm{mCi} \mathrm{Na}{ }^{125} \mathrm{I}$ and $25 \mu \mathrm{l}$ of $1 \% \beta$-D-glucose, and were incubated for $30 \mathrm{~min}$ at $22^{\circ} \mathrm{C}$. The reaction was quenched by centrifugation to remove the solidphase reagent from the reaction mixture, followed by immediate removal of the supernatant for subsequent gel filtration on Bio-Gel P6DG. Separated ${ }^{125} \mathrm{I}$-thrombin was stored at $4^{\circ} \mathrm{C}$ in $0.07 \mathrm{M}$ sodium phosphate buffer (pH 6.8) containing $0.2 \mathrm{M} \mathrm{NaCl}$ and $0.5 \%$ bovine serum albumin. The specific radioactivity incorporated into the enzyme ranged from 6 to $20 \times 10^{9} \mathrm{cpm} / \mathrm{mg}$ of protein. When analyzed by gel electrophoresis in dodecyl sulfate (25), over $95 \%$ of the ${ }^{125}$ I appeared in a peak with a migration distance identical with that of unlabeled thrombin, and no radioactivity was detected in the region of tracking dye. The thrombin activity, assayed either for clotting activity with fibrinogen as substrate or for amidolytic activity with tosyl-glycineproline-arginine-p-nitroanilide as substrate (26), was not impaired by the iodination technique and kept stable for at least $1 \mathrm{wk}$ at $4^{\circ} \mathrm{C}$. The binding to endothelial cells measured with increasing concentrations of ${ }^{125}$ I-thrombin was compared in affinity with that determined by competing for ${ }^{125} \mathrm{I}$-thrombin binding with increasing concentrations of unlabeled thrombin. The value of thrombin concentration at halfmaximal binding obtained by these two methods differed only by 10 $\pm 5 \%$ (mean \pm SE of three experiments). This indicates that iodination did not alter the properties of thrombin for the binding.

Binding of ${ }^{125}$ I-thrombin to endothelial cells. Labeled and unlabeled thrombin was appropriately diluted with RPMI-1640 medium containing $1 \mathrm{mg} / \mathrm{ml}$ of bovine serum albumin. ${ }^{125} \mathrm{I}$-thrombin with or without unlabeled thrombin was placed upon the washed endothelial cell cultures in $0.5 \mathrm{ml}$ of the same medium for $10 \mathrm{~min}$ at $37^{\circ} \mathrm{C}$. The medium was suctioned off and the cell layer was rinsed three times as quickly as possible with Hanks' balanced salt solution. Further washes caused only minimal loss of the amount specifically bound to the cells as defined below. The cells were then incubated with $0.5 \mathrm{ml}$ of $0.25 \%$ trypsin in phosphate-buffered saline for $5 \mathrm{~min}$. Trypsinization was stopped by addition of tissue culture medium containing $10 \%$ calf serum. The cell suspension was centrifuged at $1,000 \mathrm{~g}$ for $10 \mathrm{~min}$. The radioactivity in the supernatant and pellet was then counted in a $\gamma$ scintillation counter (Packard Instrument Co., Downers Grove, IL). The radioactivity in the supernatant represents thrombin that was accessible to removal by trypsin, therefore presumably thrombin bound to the cell surface. Conversely, the radioactivity in the pellet represents thrombin that was not removed by trypsin, probably because of internalization by cells. Nonspecific binding is defined as the amount of ${ }^{125}$ I-thrombin bound in the presence of a 100 -fold excess of unlabeled thrombin. Specific binding was obtained by subtracting nonspecific binding from total binding. Protein in the cells was measured according to Lowry et al. (27).

In some experiments, thrombin binding was also measured with its enzymatic activity. Unlabeled purified thrombin was incubated for 10 min with the washed endothelial cell cultures in $0.5 \mathrm{ml}$ of Hanks' balanced salt solution containing bovine serum albumin $(1 \mathrm{mg} / \mathrm{ml})$ at $37^{\circ} \mathrm{C}$. The incubation media were collected and maintained at $4{ }^{\circ} \mathrm{C}$ before assay for unbound thrombin activity. After the cell layer was rinsed three times with iced Hanks' balanced salt solution, $0.5 \mathrm{ml}$ of this solution containing bovine serum albumin was added and the cells were scraped with a rubber policeman. The cell suspension was sonicated for $10 \mathrm{~s}$ at $4^{\circ} \mathrm{C}$. Amidolytic activities of thrombin in the incubation media and in the cell homogenates were determined using the chromogenic substrate as previously described (26). The mixture of enzyme and the substrate was incubated at $37^{\circ} \mathrm{C}$ long enough to yield $0.1<A_{405}$ (usually for $3 \mathrm{~min}$ ). The readings of absorbance were repeated every minute during incubations.

Treatment of endothelial cell cultures with glycosaminoglycandegrading enzymes. Enzyme activities of the crude $F$. heparinum enzyme preparation, purified heparitinase, and chondroitin $\mathrm{ABC}$ lyase were measured by increase in $A_{232}$ due to an unsaturated double bond introduced during cleavage between the hexosamines and uronic acids with heparin, heparan sulfate, and chondroitin sulfate, respectively, as substrate. This activity was expressed as micromoles of unsaturated 
double bond appearing from each substrate per hour (21). The crude $F$. heparinum enzyme preparation contains chondroitin lyase, dermatanase, heparinase, and heparitinase activities. Purified heparitinase has essentially no activity on chondroitin sulfate, dermatan sulfate, or heparin $(<0.2 \%$ of heparitinase activity)

Washed endothelial cell cultures were incubated for $60 \mathrm{~min}$ at $37^{\circ} \mathrm{C}$ in $0.15 \mathrm{ml}$ of Hanks' balanced salt solution with $(a) 1.6 \mathrm{U} / \mathrm{ml}$ of crude $F$. heparinum enzyme, $(b) 0.6 \mathrm{U} / \mathrm{ml}$ of heparitinase, $(c) 13$ $\mathrm{U} / \mathrm{ml}$ of chondroitin $\mathrm{ABC}$ lyase, or $(d)$ no added enzyme. After the incubations, cultures were washed and assayed for thrombin binding as described above.

Effects of glycosaminoglycan-degrading enzyme treatment on ${ }^{35} \mathrm{~S}$ labeled glycosaminoglycans and ${ }^{3} \mathrm{H}$-labeled proteins on endothelial cells. Endothelial cells were labeled with $\left[{ }^{35} \mathrm{~S}\right]$ sulfate or $\left[{ }^{3} \mathrm{H}\right]$ leucine before the treatment with glycosaminoglycan lyases as previously described $(21,28)$. To achieve the labeling, culture media containing $30 \mu \mathrm{Ci} / \mathrm{ml}$ of $\left[{ }^{35} \mathrm{~S}\right]$ sulfate or $5 \mu \mathrm{Ci} / \mathrm{ml}$ of $\left[{ }^{3} \mathrm{H}\right]$ leucine were incubated with cells for 24 or for $42 \mathrm{~h}$, respectively. After removal of the medium and washing with Hanks' balanced salt solution 10 times, the cell layers were incubated for $60 \mathrm{~min}$ at $37^{\circ} \mathrm{C}$ with $0.15 \mathrm{ml}$ of Hanks' balanced salt solution containing either crude $F$. heparinum enzyme, heparitinase, or chondroitin $\mathrm{ABC}$ lyase as above. Each of the solutions was removed to provide an "enzyme" fraction, and cultures were then incubated with $0.5 \mathrm{ml}$ of $0.25 \%$ trypsin to lift the cells from the plates. The cell suspensions were centrifuged to obtain a supernate ("trypsinate" fraction) and a cell pellet ("cell" fraction). The trypsinate fraction includes glycosaminoglycans or proteins derived from the cell surface and from the solubilized matrix (28). The cultures were then treated with $0.5 \mathrm{ml}$ of $0.1 \mathrm{~N} \mathrm{NaOH}$ for removal of radioactivity remaining on the plates ("plate" fraction). The ${ }^{35}$ S-labeled glycosaminoglycans in "trypsinate" fractions were isolated by modifications of the methods described by Wasteson et al. (29) as follows: pronase (1 mg) was added to $0.4 \mathrm{ml}$ of "trypsinate" fraction from each dish. Proteolysis was continued for $3 \mathrm{~h}$ at $37^{\circ} \mathrm{C}$. For chondroitin $\mathrm{ABC}$ lyase treatments, aliquots of pronase digests were boiled for $15 \mathrm{~min}$, and after being cooled, were treated with $15 \mathrm{U} / \mathrm{ml}$ of chondroitin $A B C$ lyase for $4 \mathrm{~h}$ at $37^{\circ} \mathrm{C} \mathrm{(30)}$. Pronase digests, before or after treatments with chondroitin $\mathrm{ABC}$ lyase, were mixed with $0.1 \mathrm{ml}$ of $0.2 \mathrm{M} \mathrm{NaCl}$ containing $2 \mathrm{mg}$ of carrier chondroitin sulfate and $0.5 \mathrm{ml}$ of $1 \%$ cetylpyridinium chloride. After incubation at $37^{\circ} \mathrm{C}$ for $1 \mathrm{~h}$, the precipitate was collected by centrifugation at $2,000 \mathrm{~g}$ for $30 \mathrm{~min}$. The cetylpyridinium-glycosaminoglycan complex was dissolved in $0.1 \mathrm{ml}$ of $4 \mathrm{M} \mathrm{NaCl}$ and reprecipitated with $1.4 \mathrm{ml}$ of $80 \%$ aqueous ethanol to obtain purified glycosaminoglycans. These were dissolved in $0.4 \mathrm{ml}$ of water, and their radioactivity was measured by liquid scintillation counting.

Effects of glycosaminoglycan-degrading enzyme treatment on ${ }^{125} I-$ labeled cell surface proteins on endothelial cells. Iodination of cell surface proteins was performed in monolayer endothelial cells by minor modifications of the method of Hynes (31). After cell cultures were washed six times with Hanks' balanced salt solution, they were incubated with $20 \mu \mathrm{g} / \mathrm{ml}$ of lactoperoxidase, $0.02 \mathrm{U} / \mathrm{ml}$ of glucose oxidase, $5 \mathrm{mM}$ of $\beta$-D-glucose, and $300 \mu \mathrm{Ci} / \mathrm{ml}$ of $\mathrm{Na}^{125} \mathrm{I}$ in phosphatebuffered saline containing $0.9 \mathrm{mM}$ of $\mathrm{MgCl}_{2}$ and $\mathrm{CaCl}_{2}$ in a final volume of $0.285 \mathrm{ml}$. Reaction was allowed to continue for $15 \mathrm{~min}$ at $22^{\circ} \mathrm{C}$ with constant swirling, and was stopped by addition of cold phosphate-buffered iodide (phosphate-buffered saline with the $\mathrm{NaCl}$ replaced by $\mathrm{NaI}$ ). The medium was removed and the cells were washed three times with phosphate-buffered iodide and then six times more with Hanks' balanced salt solution. The ${ }^{125}$ I-labeled cell layers were incubated for $60 \mathrm{~min}$ at $37^{\circ} \mathrm{C}$ with $0.15 \mathrm{ml}$ of Hanks' balanced salt solution containing either crude $F$. heparinum enzyme, heparitinase, or chondroitin $\mathrm{ABC}$ lyase. Each of the solutions was removed and kept for analysis. The cells were washed once with $0.15 \mathrm{ml}$ of Hanks' balanced salt solution and the washings were pooled with the incubation solutions. The cells were then scraped into phosphate-buffered iodide and centrifuged. After one more wash with phosphate-buffered iodide, the cell pellets were dissolved in $0.2 \mathrm{ml}$ of electrophoresis sample buffer containing $2 \%$ sodium dodecyl sulfate, $1 \%$ mercaptoethanol, and $2 \mathrm{mM}$ phenylmethylsulfonyl fluoride and boiled for $2 \mathrm{~min}$ Portions of both incubation solutions and solubilized cell pellets were mixed with $15 \%$ trichloroacetic acid after addition of $1 \mathrm{mg}$ of carrier bovine serum albumin, and centrifuged. The radioactivity in the precipitate was then counted.

Slab gel electrophoresis for solubilized cell samples was carried out by the method of Laemmli (32). The slabs, after they were stained with Coomassie Blue, were dried down onto paper, and autoradiographs were made on $\mathrm{x}$-ray film (X-OMAT AR; Eastman Kodak Co., Rochester, NY).

\section{Results}

Binding of thrombin to endothelial cells. A time course of ${ }^{125} \mathrm{I}-$ thrombin binding to the surface of endothelial cell monolayers is shown in Fig. $1(\mathrm{O})$. Rapid binding occurred within 1-2 min of incubation, and then continued at a much slower rate for the next $10 \mathrm{~min}$. In the experiments to be presented, the incubation was carried out for $10 \mathrm{~min}$, and the data represent initial rapid binding of thrombin at apparent equilibrium. "Internalization" of ${ }^{125}$ I-thrombin by the cells accounted for $<25 \%$ of the total binding by cells (data not shown).

Effects of glycosaminoglycan lyase treatment and protamine sulfate on thrombin binding to endothelial cells. The specific and nonspecific binding of ${ }^{125} \mathrm{I}$-thrombin to the endothelial cell surface was determined at a concentration of $4.7 \mathrm{nM}$ of ${ }^{125} \mathrm{I}$-thrombin. Specific binding accounted for $\sim 50 \%$ of total binding. The binding after treatment of cells with glycosaminoglycan-degrading enzymes was compared with that after treatment of cells with Hanks' balanced salt solution alone. As shown in Fig. 2, both crude $F$. heparinum enzyme and heparitinase treatments caused a significant decrease of specific as well as nonspecific binding compared with that for the control. The amount specifically bound was decreased to $33 \%$

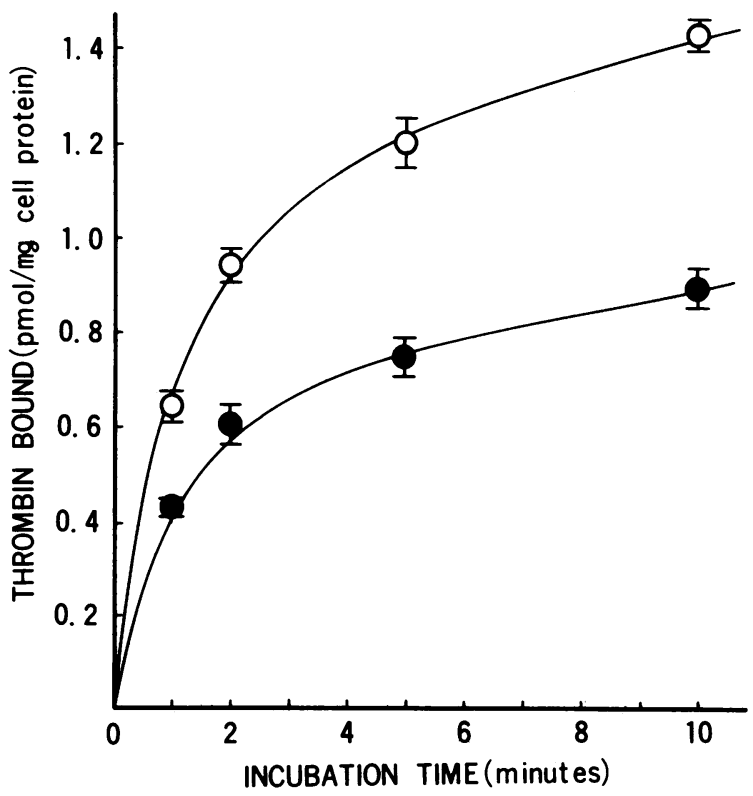

Figure 1. Time course of binding of thrombin to endothelial cells. Endothelial cell cultures ( $41 \mu \mathrm{g}$ of cell protein/dish), either without any treatment $(0)$ or after treatment with heparitinase (๑), were incubated with $7.4 \mathrm{nM}$ of ${ }^{125} \mathrm{I}$-thrombin. At the indicated times, the amount of thrombin bound to the cell surface was determined as described in Methods. Data represent the mean \pm standard error of six determinations from two separate experiments. 
THROMBIN SPECIFICALLY BOUND

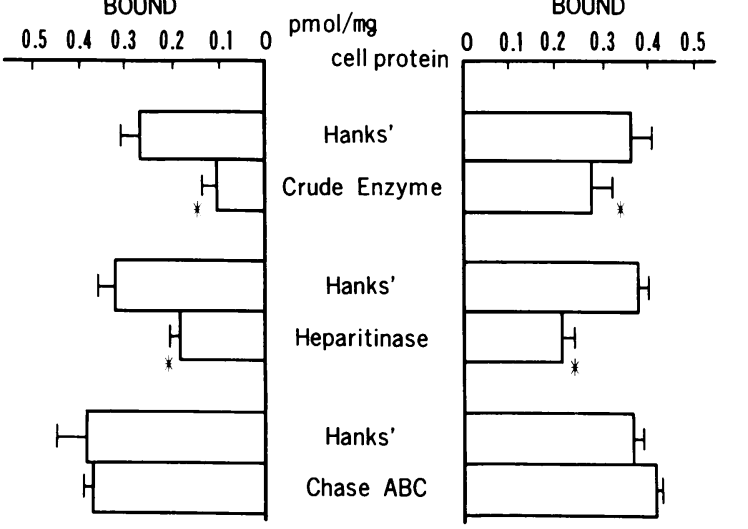

Figure 2. Effects of glycosaminoglycan-degrading enzyme treatments of endothelial cells on thrombin binding. Endothelial cell cultures (average cell protein of $66 \mu \mathrm{g} /$ dish) were incubated with $4.7 \mathrm{nM}$ of ${ }^{125} \mathrm{I}$-thrombin to determine specific and nonspecific thrombin bindings to the cell surface after treatment with either Hanks' balanced salt solution alone (Hanks'), crude $F$. heparinum enzyme (Crude Enzyme), purified heparitinase (Heparitinase), or chondroitin ABC lyase (Chase $\mathrm{ABC}$ ) as described in Methods. Each enzymatic treatment was performed in parallel with the treatment by Hanks' balanced salt solution alone as control. The data represent the mean \pm standard error of four separate experiments. ${ }^{*} P<0.05$, significantly different from the value of control (paired $t$ test, $n=4$ ).

and $58 \%$ of that for control, and nonspecific binding was reduced to $77 \%$ and $56 \%$ of control, respectively. In contrast, chondroitin $\mathrm{ABC}$ lyase treatment of cells affected neither specific nor nonspecific binding. The binding to the cells after treatment with Hanks' balanced salt solution alone did not differ from that without any treatment (data not shown).

Comparable data were obtained from the binding experiments in which the enzymatic activity of thrombin was measured. When 4.0 NIH U per dish of thrombin was incubated with endothelial cell cultures after the identical treatment with either Hanks' balanced salt solution alone, crude $F$. heparinum enzyme, heparitinase, or chondroitin $\mathrm{ABC}$ lyase, thrombin activity found in the form associated with cells was 0.15 $\pm 0.01,0.08 \pm 0.005,0.087 \pm 0.008$, or $0.14 \pm 0.001 \mathrm{NIH} U$ per dish, respectively (mean \pm standard error of three determinations). The total enzymatic activity recovered, i.e., the activity in the incubation medium plus that associated with cells, was $85 \pm 2 \%$ of the initially added thrombin activity. The recovery of the enzymatic activity was not different among variously treated cells.

In a subsequent series of experiments, binding was measured at a constant, tracer concentration of labeled thrombin, and only the unlabeled thrombin concentration was varied. The radioactivity of ${ }^{125} \mathrm{I}$-thrombin bound specifically to the cell surface was obtained at various concentrations of unlabeled thrombin, and the amount of thrombin specifically bound was calculated at each thrombin concentration in the incubation medium. Figs. 3-5 show the effects of various glycosaminoglycan-degrading enzyme treatments on specific thrombin binding to the cell surface. The amount bound to the cells appeared to reach a plateau at $60 \mathrm{nM}$ of added thrombin. The amount of thrombin specifically bound to the cells after treatment with crude $F$. heparinum enzyme (Fig. 3) or heparitinase (Fig. 4) was significantly less at each thrombin concentration than that

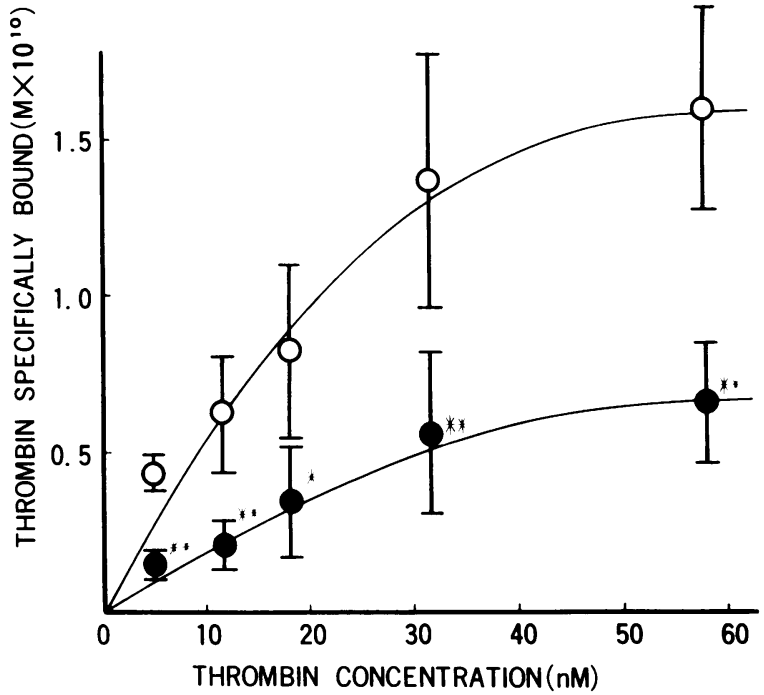

Figure 3. Binding of thrombin to the endothelial cell surface after treatment with crude $F$. heparinum enzyme. Endothelial cell cultures ( $77 \mu \mathrm{g}$ of cell protein/dish) were treated with crude $F$. heparinum enzyme (•) in parallel with the treatment by Hanks' balanced salt solution alone ( 0 ) as described in Methods. The cells were then washed and incubated with $4.8 \mathrm{nM}$ of ${ }^{125} \mathrm{I}$-thrombin in the presence of increasing concentrations of unlabeled thrombin (0-560 nM) for $10 \mathrm{~min}$ at $37^{\circ} \mathrm{C}$. The following experimental procedures were common in Figs. 3-5. Nonspecific binding (i.e., the binding in the presence of $560 \mathrm{nM}$ of unlabeled thrombin) was subtracted from binding at each thrombin concentration. The amount of thrombin specifically bound, thus obtained, was calculated based on the specific radioactivity of thrombin at each thrombin concentration in the incubation medium. The amount of cells per dish expressed in terms of cell protein was not different between experimental and control groups. Data represent the mean \pm standard error of three separate experiments. ${ }^{*} P<0.05,{ }^{* *} P<0.01$, significantly different from the value for control cells (one-tailed $t$ test, $n=3$ ).

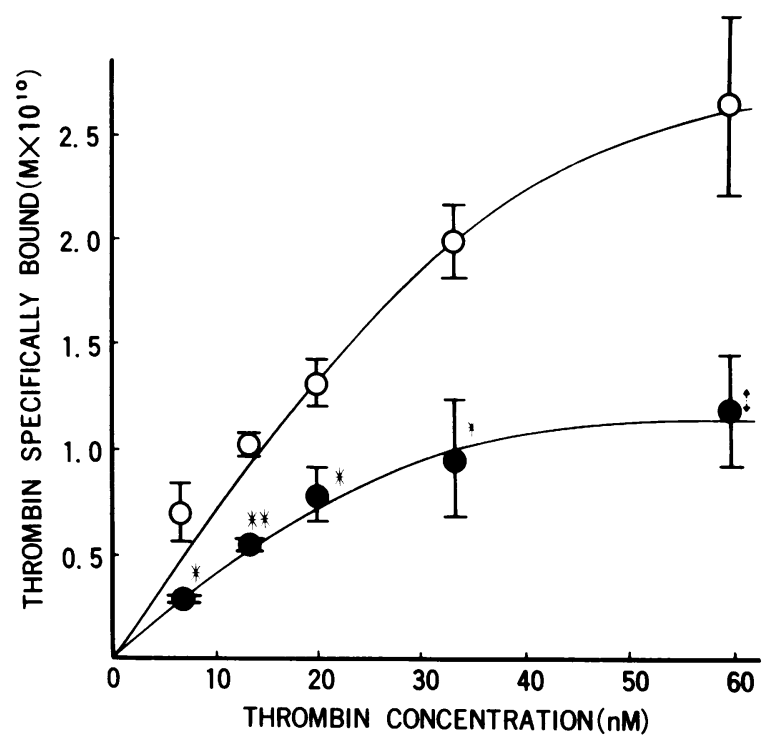

Figure 4. Binding of thrombin to the endothelial cell surface after treatment with heparitinase. Endothelial cell cultures $(89 \mu \mathrm{g}$ of cell protein/dish) were treated with heparitinase $(\bullet)$ in parallel with the treatment by Hanks' balanced salt solution alone $(0)$ as described in Methods. The cells were then incubated with $6.6 \mathrm{nM}$ of ${ }^{125} \mathrm{I}$-thrombin in the presence of increasing concentrations of unlabeled thrombin. See the legend to Fig. 3 for further details. $\uparrow P<0.06$ (onetailed $t$ test). 


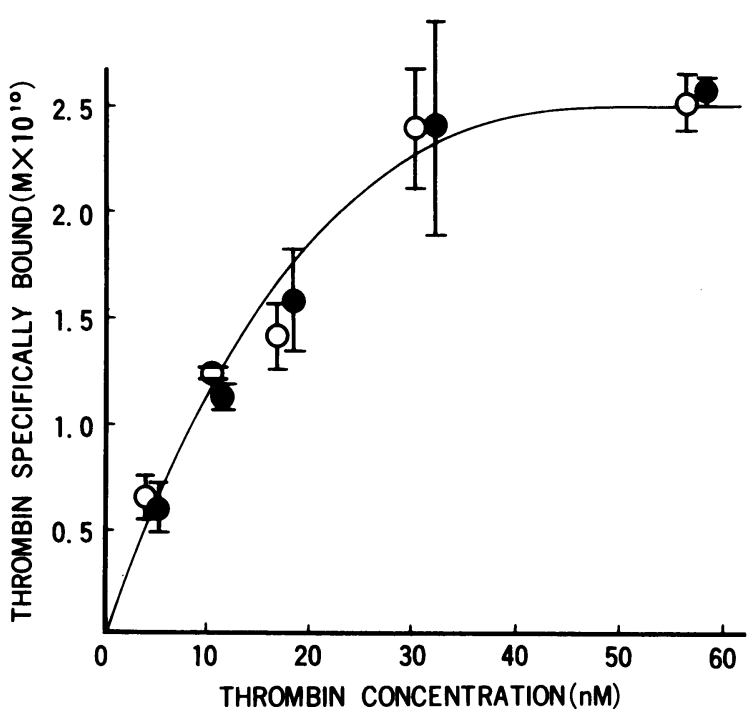

Figure 5. Binding of thrombin to the endothelial cell surface after treatment with chondroitin $\mathrm{ABC}$ lyase. Endothelial cell cultures (64

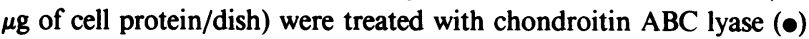
in parallel with the treatment by Hanks' balanced salt solution alone (O) as described in Methods. The cells were then incubated with 4.2 $\mathrm{nM}$ of ${ }^{125} \mathrm{I}$-thrombin in the presence of increasing concentrations of unlabeled thrombin. See the legend to Fig. 3 for further details.

after treatment with Hanks' balanced salt solution alone, and the maximal thrombin binding to the cells was reduced to 41 or $45 \%$ of that for control cells, respectively. The concentration of thrombin at half-maximal binding was $\sim 20 \mathrm{nM}$ for control cells and did not change after treatments of cells with these enzymes.

On the other hand, after treatment of cells with chondroitin $\mathrm{ABC}$ lyase, at each thrombin concentration, the amount of thrombin specifically bound was not different from that after treatment with Hanks' balanced salt solution alone (Fig. 5).

In the next experiment, ${ }^{125}$ I-thrombin binding to the endothelial cell surface was carried out in the presence of $10 \mu \mathrm{g} /$ $\mathrm{ml}$ of protamine sulfate. As shown in Fig. 6 (inset), ${ }^{125} \mathrm{I}$ thrombin bound to endothelial cell surface specifically and nonspecifically was significantly reduced to 35 and $68 \%$ of that in the absence of protamine sulfate, respectively, and at each thrombin concentration, thrombin specifically bound to the cells in the presence of protamine sulfate was considerably less, by $45-67 \%$, than that in the absence of this compound (Fig. 6). When the protamine concentration was increased from 10 to $100 \mu \mathrm{g} / \mathrm{ml}$, the same results were obtained.

Previously two independent types of binding of thrombin to endothelial cells were demonstrated (14). One type was rapid, reversible, and active site-independent, whereas the other was slow, irreversible, and active site-specific. Thrombin binding to endothelial cells after treatment with heparitinase was characterized in these respects in comparison with that after treatment with Hanks' balanced salt solution alone. Table I shows that specific thrombin binding to endothelial cells was completely displaced by an excess amount of inactive thrombin and was highly reversible. These characteristics were not changed after heparitinase treatments.

A time course of initial rapid binding of thrombin to the endothelial cells after treatment with heparitinase was also compared with that of thrombin binding to the cells without

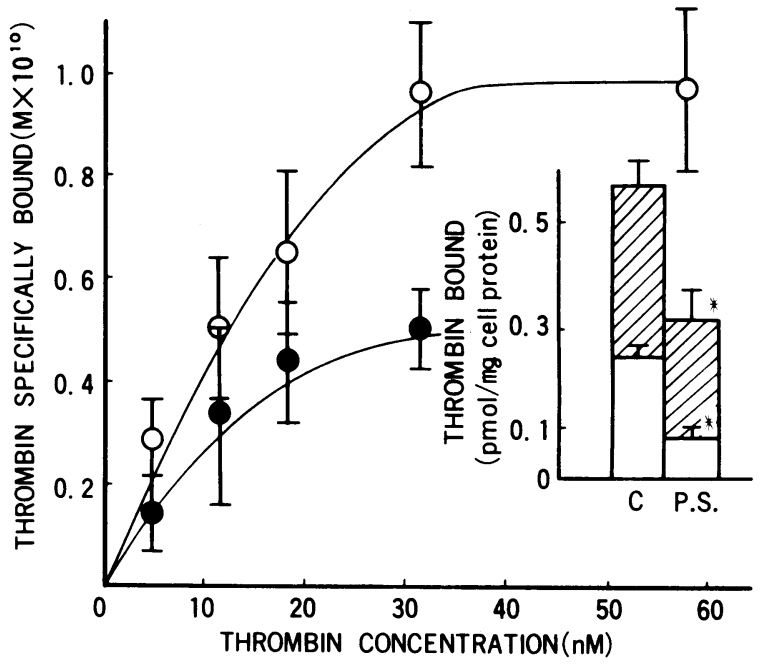

Figure 6. Effects of protamine sulfate on the binding of thrombin to endothelial cells. Endothelial cell cultures (67 $\mu \mathrm{g}$ of cell protein/dish) were incubated in the medium containing $4.8 \mathrm{nM}$ of ${ }^{125} \mathrm{I}$-thrombin and increasing concentrations of unlabeled thrombin $(0-560 \mathrm{nM})$ in the presence $(\bullet)$ or absence $(0)$ of protamine sulfate $(10 \mu \mathrm{g} / \mathrm{ml})$ for 10 min at $37^{\circ} \mathrm{C}$. Specific thrombin binding to the cell surface was then determined as indicated in the legend to Fig. 3. The mean and range of two separate experiments is shown. (Inset) Effects of protamine sulfate on the specific and nonspecific binding of thrombin to the endothelial cell surface. Endothelial cell cultures $(70 \mu \mathrm{g}$ of cell protein/dish) were incubated with $4.8 \mathrm{nM}$ of ${ }^{125} \mathrm{I}$-thrombin in the presence (P.S.) or absence (C) of protamine sulfate $(10 \mu \mathrm{g} / \mathrm{ml})$ to obtain specific (open column) and nonspecific (shaded column) thrombin binding to the cell surface as described in Methods. ${ }^{*} P<0.05$, significantly different from the value in the absence of protamine sulfate (paired $t$ test, $n=4$ ).

any treatment. As shown in Fig. 1, heparitinase treatment inhibited thrombin binding at each time point to a similar extent and did not alter a time dependence of binding.

Table I. Characterizations of Specific Thrombin Binding to Endothelial Cells After Treatments with Hanks' Balanced Salt Solution or Heparitinase

\begin{tabular}{lll}
\hline & \multicolumn{2}{c}{ Percent of specific binding } \\
\cline { 2 - 3 } Treatment of cells & $\begin{array}{l}\text { Displaceable by } \\
\text { DIP-thrombin }\end{array}$ & $\begin{array}{l}\text { Dissociable by } \\
\text { unlabeled thrombin }\end{array}$ \\
\hline & $\%$ & $\%$ \\
Hanks' & $98 \pm 5$ & $81 \pm 3$ \\
Heparitinase & $100 \pm 0$ & $74 \pm 5$
\end{tabular}

Endothelial cell cultures were treated with Hanks' balanced salt solution alone (Hanks') or purified heparitinase, then incubated with 2.7 $\mathrm{nM}$ of ${ }^{125} \mathrm{I}$-thrombin for $10 \mathrm{~min}$ at $37^{\circ} \mathrm{C}$ as described in Methods. The specific binding to the cell surface was $0.26 \pm 0.02$ and $0.15 \pm 0.01$ $\mathrm{pmol} / \mathrm{mg}$ cell protein, respectively. The binding displaceable by DIPthrombin was obtained by subtracting the binding in the presence of a 100-fold excess amount of DIP-thrombin from total binding and is shown as per cent of specific binding. For dissociation experiments, after ${ }^{125}$ I-thrombin was bound to the endothelial cell, some cultures were further incubated with $0.1 \mathrm{ml}$ of a 100-fold excess amount of unlabeled thrombin for $10 \mathrm{~min}$ at room temperature. The binding dissociable by unlabeled thrombin was determined by subtracting the binding remaining after this incubation from the initial total binding and is expressed as percent of the initial specific binding. Each value represents mean and range of two separate experiments. 
Table II. ${ }^{35} \mathrm{SO}_{4}$-labeled Compounds in Various Fractions of Endothelial Cells After Glycosaminoglycan-degrading Enzyme Treatments

\begin{tabular}{|c|c|c|c|c|}
\hline \multirow[b]{2}{*}{ Treatment of cells } & \multirow{2}{*}{$\frac{{ }^{35} \mathrm{~S}-\mathrm{GAG}}{\text { Trypsinate }}$} & \multicolumn{3}{|c|}{${ }^{35}$ S-labeled compounds } \\
\hline & & Enzyme & Cells & Plate \\
\hline Hanks' & $20,189 \pm 4,615$ & $12,592 \pm 2,081$ & $6,746 \pm 881$ & $3,040 \pm 243$ \\
\hline Crude enzyme & $2,285 \pm 299$ & $35,081 \pm 7,385$ & $5,893 \pm 718$ & $1,617 \pm 51$ \\
\hline Heparitinase & $3,212 \pm 372$ & $31,953 \pm 4,591$ & $4,989 \pm 391$ & $1,638 \pm 184$ \\
\hline Chase ABC & $16,152 \pm 4,419$ & $20,825 \pm 4,403$ & $6,539 \pm 951$ & $2,393 \pm 261$ \\
\hline
\end{tabular}

After endothelial cells were labeled with $\left[{ }^{35} S\right]$ sulfate, they were incubated with either Hanks' balanced salt solution (Hanks') alone, crude $F$. heparinum enzyme (Crude enzyme), heparitinase, or chondroitin $\mathrm{ABC}$ lyase (Chase $\mathrm{ABC}$ ). Each fraction was then obtained by trypsinizing cells as described in Methods. ${ }^{35}$ S-radioactivity in each fraction is shown except "trypsinate," in which $\left[{ }^{35}\right.$ S]glycosaminoglycans (GAG) derived from the cell surface were isolated. "Enzyme" fraction contains ${ }^{35}$ S-compounds released into the incubation medium. Data are shown as dpm/dish. Each value represents the mean \pm standard error of five determinations from three separate experiments.

Effects of glycosaminoglycan-degrading enzyme treatment on the endothelial cell surface glycosaminoglycans. Table II shows the effects of various glycosaminoglycan-degrading enzyme treatments on ${ }^{35} \mathrm{~S}$-labeled compounds in various fractions of endothelial cells. More ${ }^{35} \mathrm{~S}$-compounds were released into the medium (enzyme fraction) by all these enzymatic treatments than from the cells treated with Hanks' balanced salt solution alone. The order of the potential for release was crude $F$. heparinum enzyme $>$ heparitinase $>$ chondroitin $\mathrm{ABC}$ lyase. $\left[{ }^{35}\right.$ S $]$ glycosaminoglycans remaining on the cell surface after these enzymatic treatments were quantitated in each trypsinate fraction. After the treatment with crude $F$. heparinum enzyme or heparitinase, $\left[{ }^{35} \mathrm{~S}\right]$ glycosaminoglycan remaining on the cell surface was only 10 or $15 \%$ of that after treatment with Hanks' balanced salt solution alone, respectively, whereas, after chondroitin $\mathrm{ABC}$ lyase treatment, only $20 \%$ of $\left[{ }^{35} \mathrm{~S}\right]-$ glycosaminoglycans present on the surface of control cells was removed.

To examine whether selective and complete removal of sulfated glycosaminoglycans was achieved by these enzymatic treatments of cells, each trypsinate fraction was further exhaustively treated with chondroitin $A B C$ lyase. The $\left[{ }^{35} \mathrm{~S}\right]-$ glycosaminoglycan radioactivity in trypsinate fractions from cells treated with Hanks' balanced salt solution alone was reduced from $11,879 \pm 1,320$ to $8,005 \pm 1,101 \mathrm{dpm}$ (mean and range of two experiments) after chondroitin $\mathrm{ABC}$ lyase digestions. Thus, $\sim 30 \%$ of cell surface $\left[{ }^{35}\right.$ S $]$ glycosaminoglycans was digestible with chondroitin ABC lyase. However, $\left[{ }^{35}\right.$ S]glycosaminoglycans remaining on the cell surface after treatment with chondroitin $\mathrm{ABC}$ lyase were not more degraded.
The $\left[{ }^{35}\right.$ S]radioactivity in trypsinate fractions from the cells treated with chondroitin ABC lyase was 8,556 \pm 795 and $8,927 \pm 1,606 \mathrm{dpm}$ before and after the enzymatic digestion, respectively. The degradation by chondroitin $\mathrm{ABC}$ lyase was also observed for residual $\left[{ }^{35} \mathrm{~S}\right]$ glycosaminoglycans in trypsinate after crude $F$. heparinum enzyme or heparitinase treatment. These results indicate that a major part $(\sim 70-80 \%)$ of sulfated glycosaminoglycans associated with the surface of endothelial cells consisted of heparan sulfate, and chondroitin sulfates accounted for the rest of glycosaminoglycans. Moreover, each glycosaminoglycan on the cell surface was selectively and completely removed by the treatment of cells with the purified glycosaminoglycan lyase.

Effects of glycosaminoglycan-degrading enzyme treatment on the endothelial cell surface proteins. The potential presence of contaminating protease activity in these glycosaminoglycan lyase preparations was examined in two different ways. As shown in Table III, when endothelial cells were labeled with $\left[{ }^{3} \mathrm{H}\right]$ leucine, a slight but significant increase in the release of ${ }^{3} \mathrm{H}$-labeled compounds by crude $F$. heparinum enzyme treatment was observed compared with the release by the treatment with Hanks' balanced salt solution alone. On the other hand, release of ${ }^{3} \mathrm{H}$ by heparitinase or chondroitin $\mathrm{ABC}$ lyase treatment was not different from that by treatment with Hanks' balanced salt solution alone. When trichloroacetic acid-precipitable counts were determined, essentially the same results were obtained (data not shown).

Because $\left[{ }^{3} \mathrm{H}\right]$ leucine will label all of the endothelial cell proteins and only minor portions of these proteins are located on the cell surface, the data might be inadequate to exclude

Table III. $\left[{ }^{3} \mathrm{H}\right]$ leucine-labeled Compounds in Various Fractions of Endothelial Cells After Glycosaminoglycan-degrading Enzyme Treatments

\begin{tabular}{lllll}
\hline Treatment of cells & Enzyme & Trypsinate & Cells & Plate \\
\hline Hanks' & $12,334 \pm 1,206$ & $442,625 \pm 59,059$ & $348,803 \pm 51,689$ & $50,182 \pm 3,243$ \\
Crude enzyme & $29,919 \pm 4,419^{*}$ & $360,185 \pm 31,501$ & $470,828 \pm 75,828$ & $62,890 \pm 4,050$ \\
Heparitinase & $13,227 \pm 1,469$ & $383,993 \pm 44,708$ & $472,505 \pm 53,341$ & $68,281 \pm 8,565$ \\
Chase ABC & $13,282 \pm 1,481$ & $445,635 \pm 55,822$ & $455,767 \pm 51,207$ & $62,238 \pm 4,106$
\end{tabular}

Endothelial cells, labeled with $\left[{ }^{3} \mathrm{H}\right]$ leucine, were incubated with various glycosaminoglycan lyases. Each fraction was then obtained by trypsinizing cells as described in Methods. ${ }^{3} \mathrm{H}$-radioactivity in each fraction is shown. "Enzyme" fraction contains ${ }^{3} \mathrm{H}$-labeled proteins released into the incubation medium. Data are shown as dpm/dish. Abbreviations are as in Table II. Each value represents the mean \pm standard error of seven determinations from two separate experiments. ${ }^{*} P<0.005, t$ test, significantly different from the value for control (Hanks'). 
Table IV. Release of ${ }^{125}$ I-labeled Cell Surface Proteins by Treatments of Endothelial Cells with Glycosaminoglycandegrading Enzymes

\begin{tabular}{lc}
\hline Treatment of cells & $\begin{array}{l}\text { TCA-precipitable activity } \\
\text { released (\% of total) }\end{array}$ \\
\hline Hanks' & $9.0 \pm 0.8$ \\
Crude enzyme & $13.7 \pm 1.1^{*}$ \\
Heparitinase & $8.1 \pm 1.3$ \\
Chase ABC & $7.7 \pm 1.3$ \\
\hline
\end{tabular}

After iodination of cell surface proteins, endothelial cells were incubated with various glycosaminoglycan-degrading enzymes as described in Methods. The trichloroacetic acid (TCA)-precipitable radioactivity released into each incubation medium, after being subtracted by the amount that was obtained when identical experiments were performed on a dish containing no cells, is expressed as the percentage of ${ }^{125}$ I-labeled proteins initially present on the cell surface (TCA-precipitable radioactivity in the incubation medium plus that remaining on the cells, $975,882 \pm 86,115 \mathrm{cpm} /$ dish for the cells treated with Hanks'). Abbreviations are as in Table II. Each value represents the mean \pm standard error of four determinations from two separate experiments.

* $P<0.05, t$ test; significantly different from the value for control (Hanks').

proteolysis of cell surface proteins. Therefore, in the next experiment, the cell surface proteins were specifically labeled with ${ }^{125} \mathrm{I}$ and the effects of glycosaminoglycan-degrading enzyme treatment on these ${ }^{125}$ I-labeled proteins were tested. As shown in Table IV, release of trichloroacetic acid-precipitable radioactivity by heparitinase or chondroitin $\mathrm{ABC}$ lyase treatment was not different from that by the treatment with Hanks' balanced salt solution alone. However, a slight but significant increase in the release of these compounds was demonstrated by crude $F$. heparinum enzyme treatment. Thus, the results obtained by two different methods were consistent. Furthermore, the distribution of cell surface proteins after glycosaminoglycan-degrading enzyme treatments was compared with that after treatment with Hanks' balanced salt solution alone. ${ }^{125}$ I-labeled endothelial cells after the various enzyme treatments were subjected to sodium dodecyl sulfate gel electrophoresis and autoradiography. As shown in Fig. 7, the pattern (the proportion or mobility) of the labeled cell surface proteins in these gels was not altered by these glycosaminoglycan lyase treatments.

\section{Discussion}

The specific binding of thrombin to the surface of endothelial cells was rapid, reversible, and completely displaced by DIPthrombin. These characteristics are consistent with the results previously reported $(13,14)$ for thrombin binding to human umbilical vein endothelial cells after a short-term incubation. Our binding studies revealed that thrombin concentration at half-maximal binding for specific binding to endothelial cells was $\sim 20 \mathrm{nM}$, which was substantially higher than the value for the dissociation constant $\left(K_{d}\right)$ described by Lollar et al. (14) ( $3 \mathrm{nM})$, but agreed with the value reported by Bauer et al. (18) (30 nM). It should be noted that using in vivo rabbit preparations, $K_{\mathrm{d}}$ for high-affinity binding sites on endothelium recognized by DIP-thrombin was demonstrated to be approximately $10 \mathrm{nM}$ (3), close to our in vitro data.

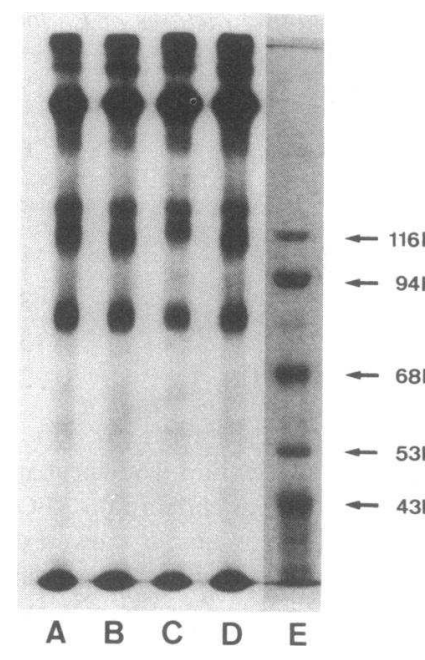

Figure 7. Autoradiograms of iodinated cell surface proteins from endothelial cells after treatments with various glycosaminoglycan lyases. After iodination of cell surface proteins, cells were treated with $(A)$ Hanks' balanced salt solution alone, $(B)$ heparitinase, $(C)$ chondroitin $\mathrm{ABC}$ lyase, and $(D)$ crude $F$. heparinum enzyme as described in Methods. Solubilized cell pellets (20,000 cpm for each sample) were loaded on sodium dodecyl sulfate $7.5 \%$-polyacrylamide slab gel electrophoresis. The gels were stained, dried, and subjected to autoradiography on X-ray film for $18 \mathrm{~h}$ at $-70^{\circ} \mathrm{C}$. Track $E$ shows the Coomassie stain of the marker proteins run in parallel with the labeled proteins: $\beta$-galactosidase (116,000 mol wt), phosphorylase a $(94,000 \mathrm{~mol} \mathrm{wt})$, bovine serum albumin $(68,000 \mathrm{~mol} \mathrm{wt})$, glutamate dehydrogenase $(53,000 \mathrm{~mol} \mathrm{wt})$, ovalbumin $(43,000 \mathrm{~mol} \mathrm{wt}) . \mathrm{K}$, molecular weight: e.g., $116 \mathrm{~K}=116,000 \mathrm{~mol} \mathrm{wt}$.

The treatment of cells with crude $F$. heparinum enzyme or heparitinase reduced the amount of thrombin bound both specifically and nonspecifically to endothelial cells. The binding data obtained by measuring the enzymatic activity of thrombin indicated that thrombin associated with the cells was functionally active at least toward the synthetic substrate, and provided further evidence that it was actually active thrombin binding, which was inhibited by the enzymatic treatments of cells. When the amount of thrombin specifically bound was measured as a function of thrombin concentration, it was indicated that the amount of maximal thrombin binding was reduced by $\sim 50 \%$ with little alteration in binding affinity. This was further supported by a time-course study which showed that the rate of binding was not altered by the heparitinase treatment, whereas the amount of binding at each time point was reduced. On the other hand, chondroitin $\mathrm{ABC}$ lyase treatment did not influence the thrombin binding by the cells. Identical enzymatic treatments of $\left[{ }^{35} \mathrm{~S}\right]$ sulfate-labeled cells showed that either heparan sulfate or chondroitin sulfate was selectively and completely removed from the cell surface by heparitinase or chondroitin $\mathrm{ABC}$ lyase treatment, respectively. Furthermore, identical enzymatic treatments of $\left[{ }^{3} \mathrm{H}\right]$ leucine-labeled or cell surface-radioiodinated endothelial cells revealed that the purified glycosaminoglycan lyase treatments did not cause any breakdown of cell surface proteins, although some contaminations with proteinase were apparent in crude $F$. heparinum enzyme preparations. These results strongly support the concept that heparan sulfate on the cell surface plays a role in at least some part of the high-affinity thrombin binding to endothelial cells. The results obtained with the heparin antagonist protamine sulfate are consistent with this view and agree with the recent finding by Dryjski et al. (9) in which they reported that protamine caused a decrease of $\sim 50 \%$ of thrombin bound to the endothelium on aortic segments.

Our data also suggest the presence of thrombin binding sites that are not directly related to heparan sulfate. Thrombin binding to these sites is also reversible and displaced by DIP- 
thrombin. Although thrombin-thrombomodulin interaction is competitively inhibited by DIP-thrombin, the estimated $K_{\mathrm{m}}$ for this reactin is reported to be $\sim 0.5 \mathrm{nM}(20)$, far below the value for thrombin concentration at half-maximal binding in the present study. Thus, thrombomodulin may be unlikely to account for the observed radiolabeled thrombin-binding site other than heparan sulfate. Because thrombin that is blocked from the heparin-binding site by chemical modifications has been shown to completely lose its ability to bind to highaffinity sites (18), our data may indicate that thrombin-binding sites that are not related to heparan sulfate but still interact with the heparin-binding domain of thrombin are present on the endothelium. If heparan sulfate on the cell surface would represent distinct binding sites for thrombin involving approximately a half of the high-affinity thrombin receptors on endothelial cells, it is not now known what accounts for the rest of the binding sites. Alternatively, heparan sulfate might form part of the surface receptor structure for thrombin and thereby its removal leads to the reduction of the number of thrombin molecules bound per receptor site. Our data provide no adequate information on these questions.

It has been speculated that a heparin-like substance present on the endothelial cell surface is responsible for the anticoagulant property of the endothelium $(2,12)$. In fact, some evidence in support of this concept has appeared. This evidence includes direct or indirect characterizations of anticoagulant activity of heparin-like species on endothelium $(8,9,33,34)$. Lollar and Owen (3) and Busch and Owen (8) have proposed that the inactivation of thrombin by antithrombin III is catalyzed by the active site-independent high-affinity binding sites on the endothelial cell surface, based on their series of experiments that used in vivo and in vitro cell culture preparations. The present finding has provided the first direct evidence that heparan sulfate on the endothelial cell surface is indeed involved in the high-affinity, active site-independent thrombin binding by these cells. In the most recent report, by perfusing rat hindlimb preparations with purified thrombin and with antithrombin, Marcum et al. (35) have found that the vascular endothelium can accelerate thrombin-antithrombin interactions, and that heparinlike substances are responsible for this activity. Furthermore, they have concluded that thrombin bound to the endothelium, as well as enzyme free in solution, are neutralized by "activated" antithrombin, inasmuch as inhibition of thrombin binding to the endothelium by addition of DIP-thrombin to the system reduced the amount of thrombin-antithrombin complex formed by $30-40 \%$. On the other hand, using recirculating Langendroff preparations with purified reagents, Lollar et al. (36) found that binding of thrombin to the sites on the microvascular endothelium had no effect on the reaction of the enzyme with antithrombin III. Thus, whether heparan sulfate responsible for thrombin binding observed in the present study is related to the anticoagulant activity such as cofactor for antithrombin III on endothelium, as has been postulated, is yet to be determined. Alternatively, if bound thrombin is less active than free enzyme toward procoagulant substrates such as fibrinogen, thrombin clearance by the endothelium in itself would serve an anticoagulant role in hemostasis.

Buonassisi et al. (37) have demonstrated that heparan sulfate proteoglycans produced by endothelial cell cultures exhibit a wide range of structural diversity and raised the possibility that the various heparan sulfate proteoglycans may have different binding specificities and therefore play different functional roles by activating or inhibiting different enzyme systems. If this would be true, it is possible that only a portion of heparan sulfate on the cell surface may bind thrombin. And furthermore, only a certain subclass of endothelial cell surface heparan sulfate involved in thrombin binding may catalize thrombin-antithrombin III reaction.

Also note that the present findings are confined to the in vitro system using cell culture and defined reagents. In plasma, there are much greater amounts of several other heparinbinding proteins including a potent heparin antagonist, histidine-rich glycoprotein (38), and heparin cofactor, antithrombin III (35). Therefore, what, and to what extent, is bound to heparin-like species on the vascular endothelial cell surface in vivo is yet to be clarified.

\section{Acknowledgments}

The authors thank Dr. Takashi Morita for generously providing purified bovine thrombin and for his expert advice, Dr. Takashi Okuyama for providing crude $F$. heparinum enzyme, Dr. Hisakazu Ogura for the statistical analysis, Ms. Miki Murai and Ms. Sachiko Kadota for their expert technical assistance, and Dr. Barry L. Fanburg for a critical reading of the manuscript.

This work was supported in part by research grants nos. 57570352 and 59570366 from the Ministry of Education, Science and Culture, and No. 58C-1 for cardiovascular disease from the Ministry of Health and Welfare, Japan, and by a research grant for 1982 from the Japan Heart Foundation.

\section{References}

1. Wall, R. T., and L. A. Harker. 1980. The endothelium and thrombosis. Annu. Rev. Med. 31:361-371.

2. Owen, W. G. 1982. The control of hemostasis. Role of endothelium in the regulation of inhibitory and catabolic pathways. Arch. Pathol. Lab. Med. 106:209-213.

3. Lollar, P., and W. G. Owen. 1980. Clearance of thrombin from circulation in rabbits by high-affinity binding sites on endothelium. Possible role in the inactivation of thrombin by antithrombin III. $J$. Clin. Invest. 66:1222-1230.

4. Shifman, M. A., and S. V. Pizzo. 1983. In vivo metabolism of reversibly inhibited $\alpha$-thrombin. Biochem. Pharmacol. 32:739-741.

5. Shifman, M. A., and S. V. Pizzo. 1982. The in vivo metabolism of antithrombin III and antithrombin III complexes. J. Biol. Chem. 257:3243-3248.

6. Dryjski, M., P. Olsson, and J. Swedenborg. 1982. Uptake and inhibition of thrombin by the vascular wall. Thromb. Res. 27:467475 .

7. Rosenberg, R. D., J. Marcum, and J. McKenney. 1983. In vivo acceleration of antithrombin action by heparin-like molecules on the endothelium. Thromb. Haemostasis. 50:266. (Abstr.)

8. Busch, C., and W. G. Owen. 1982. Identification in vitro of an endothelial cell surface cofactor for antithrombin III. Parallel studies with isolated perfused rat hearts and microcarrier cultures of bovine endothelium. J. Clin. Invest. 69:726-729.

9. Dryjski, M., R. Larsson, P. Olsson, and J. Swedenborg. 1983. Effect of glycosaminoglycans and antithrombin III on uptake and inhibition of thrombin by the vascular wall. Thromb. Res. 32:355363.

10. Buonassisi, V., and M. Root. 1975. Enzymatic degradation of heparin related mucopolysaccharides from the surface of endothelial cell cultures. Biochim. Biophys. Acta. 385:1-10. 
11. Simionescu, M., N. Simionescu, J. E. Silbert, and G. E. Parade. 1981. Differentiated microdomains on the luminal surface of the capillary endothelium. II. Partial characterization of their anionic sites. J. Cell Biol. 90:614-621.

12. Damus, P. S., M. Hicks, and R. D. Rosenberg. 1973. A generalized view of heparin's anticoagulant action. Nature (Lond.) 246: 355-357.

13. Awbrey, B. J., J. C. Hoak, and W. G. Owen. 1979. Binding of human thrombin to cultured human endothelial cells. J. Biol. Chem. 254:4092-4095.

14. Lollar, P., J. C. Hoak, and W. G. Owen. 1980. Binding of thrombin to cultured human endothelial cells. Nonequilibrium aspects. J. Biol. Chem. 255:10279-10283.

15. Isaacs, J., N. Savion, D. Gospodarowicz, and M. A. Shuman. 1981. Effect of cell density on thrombin binding to a specific site on bovine vascular endothelial cells. J. Cell Biol. 90:670-674.

16. Savion, N., J. D. Isaacs, D. Gospodarowicz, and M. A. Shuman. 1981. Internalization and degradation of thrombin and up regulation of thrombin binding sites in corneal endothelial cells. J. Biol. Chem. 256:4514-4519.

17. Dryjski, M., P. Olsson, and J. Swedenborg. 1983. The vascular endothelium as an inhibitor of thrombin. 1983. Thromb. Res. 5(Suppl.): 67-72.

18. Bauer, P., R. Machovich, P., Arányi, K. G. Büki, E. Csonka, and I. Horváth. 1983. Mechanism of thrombin binding to endothelial cells. Blood. 61:368-372.

19. Busch, P. C., and W. G. Owen. 1982. Interactions of thrombin with endothelium. In Pathobiology of the Endothelial Cell. H. L. Nossel and H. J. Vogel, editors. Academic Press, Inc., New York. 97101.

20. Owen, W. G., and C. T. Esmon. 1981. Functional properties of an endothelial cell cofactor for thrombin-catalyzed activation of protein C. J. Biol. Chem. 256:5532-5535.

21. Shimada, K., P. J. Gill, J. E. Silbert, W. H. J. Douglas, and B. L. Fanburg, 1981. Involvement of cell surface heparan sulfate in the binding of lipoprotein lipase to cultured bovine endothelial cells. J. Clin. Invest. 68:995-1002.

22. Linker, A., and P. Hovingh. 1972. Heparinase and heparitinase from Flavobacteria. Methods Enzymol. 28:902-911.

23. Kasahara, Y., and Y. Ashihara. 1981. Colorimetry of Angiotensin-1 converting enzyme activity in serum. Clin. Chem. 27:19221925.

24. Morita, T., H. Nishibe, S. Iwanaga, and T. Suzuki. 1974. Studies on the activation of bovine prothrombin. Isolation and characterization of the fragments released from the prothrombin by activated factor X. J. Biochem. 76:1031-1048.
25. Weber, K., and M. Osborn. 1963. The reliability of molecular weight determinations by dodecyl sulfate-polyacrylamide gel electrophoresis. J. Biol. Chem. 244:4406-4412.

26. Svendsen, L., B. Blombäck, M. Blombäck, and P. I. Olsson. 1972. Synthetic chromogenic substrates for determinations of trypsin, thrombin and thrombin-like enzymes. Thromb. Res. 1:267-278.

27. Lowry, O. H., N. J. Rosebrough, A. L. Farr, and R. J. Randall. 1951. Protein measurement with Folin phenol reagent. J. Biol. Chem. 193:265-275.

28. Gill, P. J., J. Adler, C. K. Silbert, and J. E. Silbert. 1981. Removal of glycosaminoglycans from the cultures of human skin fibroblasts. Biochem. J. 194:299-307.

29. Wasteson, Å., K. Uthne, and B. Westermark. 1973. A novel assay for the biosynthesis of sulphated polysaccharide and its application to studies on the effects of somatomedin on cultured cells. Biochem. J. 136:1069-1074.

30. Yamagata, T., H. Saito, O. Habuchi, and S. Suzuki. 1968. Purification and properties of bacterial chondroitinases and chondrosulfatases. J. Biol. Chem. 243:1523-1535.

31. Hynes, R. O. 1973. Alteration of cell-surface proteins by viral transformation and by proteolysis. Proc. Natl. Acad. Sci. USA. 70: 3170-3174.

32. Laemmli, U. K. 1970. Cleavage of structural proteins during the assembly of the head of bacteriophage T4. Nature (Lond.) 227: 680-685.

33. Marcum, J. A., L. Fritze, S. J. Galli, G. Karp, and R. D. Rosenberg. 1983. Microvascular heparinlike species with anticoagulant activity. Am. J. Physiol. 245:H725-H733.

34. Colburn, P., and V. Buonassisi. 1982. Anti-clotting activity of endothelial cell cultures and heparan sulfate proteoglycans. Biochem. Biophys. Res. Commun. 104:220-227.

35. Marcum, J. A., J. B. McKenney, and R. D. Rosenberg. 1984. Acceleration of thrombin-antithrombin complex formation in rat hindquarters via heparinlike molecules bound to the endothelium. $J$. Clin. Invest. 74:341-350.

36. Lollar, P., S. C. MacIntosh, and W. G. Owen. 1984. Reaction of antithrombin III with thrombin bound to the vascular endothelium. Analysis in a recirculating perfused rabbit heart preparation. J. Biol. Chem. 259:4335-4338.

37. Buonassisi, V., and P. Colburn. 1983. Antibodies to the heparan sulfate proteoglycans synthesized by endothelial cell cultures. Biochim. Biophys. Acta. 760:1-12.

38. Lijnen, H. R., M. Hoylaerts, and D. Collen. 1983. Heparin binding properties of human histidine-rich glycoprotein. Mechanism and role in the neutralization of heparin in plasma. J. Biol. Chem. 258:3803-3808. 